\title{
The anatomy of an albite-type granitic pegmatite from the Totoral pegmatite field, San Luis, Argentina
}

\author{
Miguel Ángel GALLISKI ${ }^{*}$, María Florencia MÁRQUEZ-ZAVALÍA ${ }^{1,2}$, Petr ČERNÝ', Julio César \\ OYARZÁBAL ${ }^{4}$, Ana Cecilia MUGAS LOBOS'
}

\author{
${ }^{1}$ IANIGLA, CCT-MENDOZA CONICET, Av. Ruiz Leal s/n, Parque Gral. San Martín, C.C. 330 (5.500) Mendoza, Argentina; \\ galliski@mendoza-conicet.gob.ar \\ ${ }^{2}$ Mineralogía y Petrología, FAD, Universidad Nacional de Cuyo, Centro Universitario, (5502) Mendoza, Argentina \\ ${ }^{3}$ Department of Geological Sciences, University of Manitoba, Winnipeg, Manitoba R3T 2N2, Canada \\ ${ }^{4}$ Secretaría de Minería, Provincia de Córdoba, H. Yrigoyen 401, 5000, Córdoba, Argentina \\ *Corresponding author
}

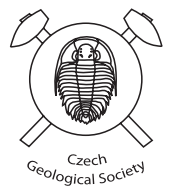

The Independencia Argentina albite-type granitic pegmatite is the most distal differentiate in the Cerro La Torre pegmatite group, located in the Eastern Pampean Ranges of Argentina. It is a zoned pegmatite formed at two main stages that probably shared the same origin but had separate evolutions.

The product of the first stage was a pegmatite dominated by albite, quartz and muscovite, with rare K-feldspar and muscovite + albite pseudomorphs after spodumene, and accessory columbite-group minerals, beryl, fluorapatite as well as garnet. This first-stage pegmatite was emplaced forcefully and crystallized syn-kinematically. Resulting boudinage and necking-down produced the main body, bulbous in shape and asymmetric in zoning.

This pegmatite was subsequently intruded by a melt that solidified to a very fine-grained, saccharoidal albite unit, composed in excess of $97 \%$ by $\mathrm{Ab}_{99,1-99.6}$, with accessory columbite-group minerals and fluorapatite. The normative mineral composition of this unit corresponds very well with that of the experimental products of protracted fractionation of rare-element pegmatite melts, with high $\mathrm{Na} / \mathrm{K}$ ratios and HFSE enrichment. The spatial and temporal association of the two pegmatitic melts, one enriched in $\mathrm{H}_{2} \mathrm{O}$ and the other one more evolved, Na-rich, almost alkaline and flux-bearing, strongly suggests that the two are cogenetic. They probably represent products of a rare-element pegmatite magma differentiation at depth that were extracted at different stages of its crystallization and emplaced at higher crustal levels.

Keywords: pegmatite, albite-type, HFSE flux-rich melt, two-stage process

Received: 29 November 2013; accepted: 5 December 2014; handling editor: Milan Novák

\section{Introduction}

Albite-type pegmatites are the least widespread and least studied in the rare-element (REL)-Li subclass of the LCT family, according to Černý and Ercit (2005). Few occurrences have been described in detail: the same authors listed only a few localities scattered in China, Canada, Spain, Australia, Argentina and Russia. The origin of albite-type pegmatites has been unclear until recently (Černý 1992), but the derivation of the melts directly by fractionation of the parental leucogranites or their separation from spodumene pegmatites is now experimentally justified (London 2008). Albite-dominant assemblages formed at the final stages of the pegmatite crystallization are well known to be significant and responsible for some of the most economically interesting tantalum mineralization in other REL-Li pegmatite types (e.g., Tanco, Černý 2005), in pegmatite districts (e.g., Wodgina, Sweetapple and Collins 2002), and in rare-element mineralized granite cupolas (Pollard 1989). We present new chemical analyses of the principal and accessory minerals, and we complement interpretations for one albite-pegmatite locality in Argentina, the Independencia Argentina pegmatite (IA), that was preliminarily described by Galliski et al. (1994).

\section{Geological setting}

The IA albite-type pegmatite belongs to the Cerro La Torre pegmatite group (Fig. 1), which in turn is the northern group of the Totoral pegmatite field located in the southern end of the San Luis range, Eastern Pampean Ranges of Argentina. The pegmatites of the Totoral field intruded a thick psammopelitic sequence of Cambrian sediments at the western margin of Gondwana (Oyarzábal et al. 2009 and references therein). During the collisional Famatinian Orogeny $(\sim 500-440 \mathrm{Ma})$, the sedimentary pile underwent Abukuma-type metamorphism giving rise to a strongly folded sequence that grades from west to east from granulite to migmatite, gneiss, mica schist and phyllite arranged in NNE-SSW trending belts, collec- 


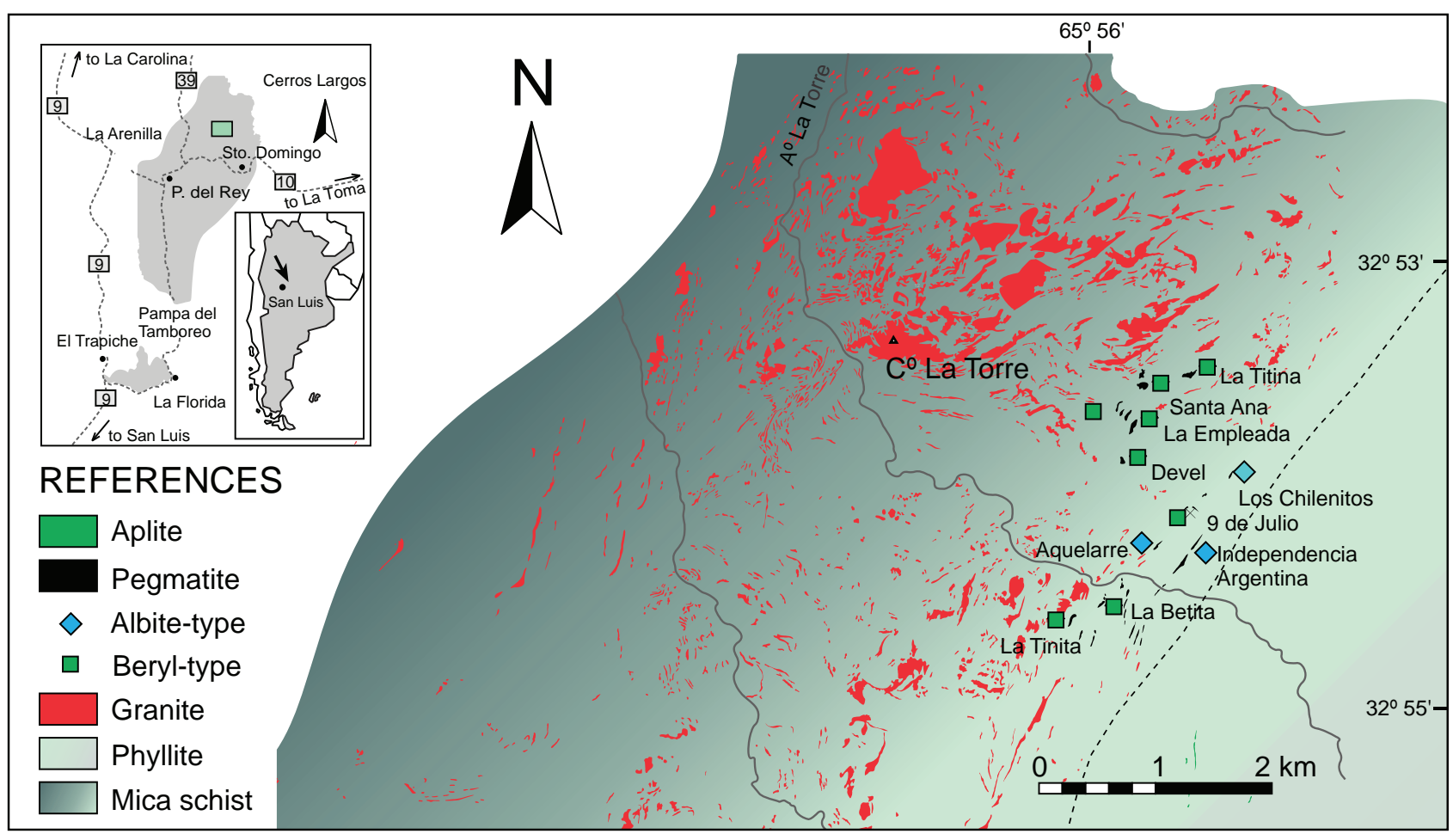

Fig. 1 Location map of the Cerro La Torre pegmatitic group, modified from Oyarzábal et al. (2009). The dashed line represents the approximate transition from mica schist to phyllite.

tively named the Pringles Metamorphic Complex (Sims et al. 1998). The age of the metamorphism varies between $484 \pm 7 \mathrm{Ma}$ and $452 \pm 19 \mathrm{Ma}$ (Sims et al. 1998; Steenken et al. 2011 and references therein). The Totoral pegmatite field is composed of two small leucogranite stocks intruded in the mica schist and a swarm of granitic sills, dykes, pegmatites, and aplites developed asymmetrically at the eastern flank of the leucogranites. The granites and pegmatite swarms show clear evidence of deformation supporting the interpretation of crystallization under a protracted compressive tectonic regime.

The northern stock, known as Cerro La Torre, is a small ( $<2 \mathrm{~km}^{2}$ in outcrop) pegmatitic leucogranite, composed of a few hundred of lenses and sills that include inliers of metamorphic rocks. Intrusion produced a partial metamorphic overprint in the mica schist, which developed nodules of cordierite or muscovite (locally fibrolite) and widespread tourmalinization. The two most common rock types are a fine-grained monzogranite and a more potassic, pegmatitic rock, both composed of Qz $+\mathrm{Kfs}+$ $\mathrm{Pl}+\mathrm{Ms} \pm \mathrm{Grt} \pm \mathrm{Tur} \pm \mathrm{Ap}$ (abbreviations after Whitney and Evans 2010). They are high silica ( 75 wt. $\left.\% \mathrm{SiO}_{2}\right)$, strongly peraluminous (Aluminium Saturation Index: $\mathrm{ASI}=[\mathrm{Al} /(\mathrm{Ca}-1.67 \mathrm{P}+\mathrm{Na}+\mathrm{K})]=1.11-1.23)$ S-type granites that yield low zircon-saturation temperatures $\left(641-726^{\circ} \mathrm{C}\right)$ (Galliski 2013).

The distribution of pegmatites in the eastern side of the Cerro La Torre leucogranite defines a regional pattern.
Beryl-columbite-phosphate subtype pegmatites containing beusite-lithiophilite phosphate assemblages occur near the granite and pass eastwards to albite-type pegmatites very near to the transition from mica schist to phyllite (Oyarzábal et al. 2009). The beryl-type pegmatites are disharmonically folded showing evidence of strong deformation. In contrast, the albite-type pegmatites are sub-concordant and show textural evidence of synkinematic strain in the bulbous shape, segmented bodies of medium-grained muscovite, bent flakes of muscovite, and broken and filled crystals of columbite-group minerals. The albite-type pegmatites are (a) IA, which is the most typical, (b) Aquelarre, which has a minor saccharoidal albite unit and has less defined internal zoning than IA, and (c) Los Chilenitos, which has features intermediate between the beryl and albite types of REL-Li pegmatites. Southeast of these pegmatites, thin dykes of quartz + tourmaline occur near the contact between mica schist and phyllite. Farther away, thin sub-concordant dykes of fine grained metavolcanic rocks are mineralized with scheelite ( $\pm \mathrm{Au}-\mathrm{Sb}$ : gold and stibnite). The plot of $\mathrm{K} / \mathrm{Rb}$ vs. Cs for K-feldspars from Cerro La Torre granites and the intermediate zones of the pegmatites shows a linear fractionation trend (Fig. 2, Oyarzábal et al. 2009). This, together with the known ages for the granites and pegmatites of the Totoral pegmatite field (centred at $\sim 455 \mathrm{Ma}$, von Quadt and Galliski 2011), supports the interpretation that all of them are cogenetic (Galliski 2013). 


\section{Experimental methods}

Samples of different minerals of the pegmatite were selected for specific analyses. K-feldspar samples of $0.3-0.4 \mathrm{~kg}$ were taken from different specimens, triturated in an Abich mortar and manually purified under binocular microscope before milling for building XRF pellets following the practice of Galliski et al (1997). Samples of the saccharoidal albite unit were collected, $\sim 0.5 \mathrm{~kg}$ each, from parts not visibly mineralized with columbite-group minerals or fluorapatite and milled for whole-rock chemical analyses performed by XRF at XRAL Activation Services Inc. at Ann Arbor, Michigan, USA.

Accessory minerals were picked under a binocular microscope. Polished sections of these minerals were examined in reflected light under a polarizing microscope before carbon-coating for electron-microprobe analysis (EMPA). The EMPA of the columbite-group minerals of samples IA9 and IA10 were performed in wavelengthdispersion mode on a Cameca SX50 instrument at Department of Geology, Virginia Polytechnic Institute, Blacksburg, VA, USA, with a beam diameter of $3 \mu \mathrm{m}$ and an acceleration potential of $15 \mathrm{kV}$. A sample current of $30 \mathrm{nA}$ measured on Faraday cup and a peak counting time of $20 \mathrm{~s}$, with background count-time of $10 \mathrm{~s}$ were used for all elements. The standards, analytical lines selected and limits of detection (wt. \%) were as follows: $\mathrm{Mg}$ (forsterite, $K_{a}, 0.01$ ), $\mathrm{Si}$ (diopside, $\left.K_{a}, 0.02\right)$, $\mathrm{Ti}\left(\mathrm{TiO}_{2}\right.$, $\left.K_{\alpha}, 0.02\right), \mathrm{Mn}\left(\mathrm{MnO}_{2}, K_{\alpha}, 0.05\right), \mathrm{Fe}\left(\mathrm{Fe}_{2} \mathrm{O}_{3}, K_{\alpha}, 0.06\right), \mathrm{Zr}$ $\left(\mathrm{ZrO}_{2}, L_{\alpha}, 0.05\right), \mathrm{Nb}\left(\mathrm{Nb}, L_{\alpha}, 0.08\right), \mathrm{Sn}\left(\mathrm{Sn}, L_{\alpha}, 0.07\right), \mathrm{Ta}$ (tantalite, $\left.M_{\alpha}, 0.08\right), \mathrm{W}\left(\mathrm{W}, L_{\alpha}, 0.35\right)$, Th $\left(\mathrm{ThO}_{2}, M_{\alpha}, 0.09\right)$ and $\mathrm{U}\left(\mathrm{UO}_{2}, M_{\beta}, 0.13\right)$.

The EMPA of the main and accessory minerals in samples IA-01 and IA-02 were performed in the wavelength-dispersion mode at LAMARX, Universidad Nacional de Córdoba, Argentina, using a Jeol JXA-8200 Superprobe with a beam diameter of $3 \mu \mathrm{m}$ and an acceleration potential of $15 \mathrm{kV}$. A sample current of $20 \mathrm{nA}$ measured on a Faraday cup and a counting time of $10 \mathrm{~s}$ for the peaks and $5 \mathrm{~s}$ for the background were used. The standards, analytical lines and limits of detection (wt. \%) were as

Fig. $2 \mathrm{~K} / \mathrm{Rb}$ vs. Cs plot for K-feldspars from granites and pegmatites of the Cerro La Torre pegmatitic group, modified from Oyarzábal et al. (2009). follows: $\mathrm{F}$ (topaz, $K_{\alpha}, 0.02$ ), $\mathrm{Na}$ (anorthoclase, $K_{\alpha}, 0.01$ ), $\mathrm{Mg}$ (forsterite, $K_{\alpha}, 0.01$ ), $\mathrm{Al}$ (anorthoclase, $K_{\alpha}, 0.01$ ), $\mathrm{Si}$ (rhodonite, $K_{\alpha}, 0.01$ ), P (lithiophilite, $K_{\alpha}, 0.01$ ), S (celestine, $\left.K_{\alpha}, 0.04\right), \mathrm{Cl}$ (sodalite, $K_{\alpha}, 0.01$ ), $\mathrm{K}$ (orthoclase, $K_{\alpha}$, $0.01)$, Ca (wollastonite, $\left.K_{\alpha}, 0.01\right), \mathrm{Sc}\left(\mathrm{ScPO}_{4}, K_{\alpha}, 0.03\right)$, $\mathrm{Ti}\left(\mathrm{TiO}_{2}, K_{a}, 0.01\right), \mathrm{Mn}$ (rhodonite, $\left.K_{a}, 0.02\right), \mathrm{Fe}$ (fayalite, $\left.K_{\alpha}, 0.02\right)$, Zn (ZnO, $\left.K_{\alpha}, 0.03\right)$, As (mimetite, $\left.K_{\alpha}, 0.02\right)$, Sr (celestine, $L, 0.03), \mathrm{Zr}\left(\mathrm{ZrO}_{2}, L_{\alpha}, 0.04\right), \mathrm{Nb}$ (samarskite, $\left.L_{\alpha}, 0.06\right), \mathrm{Sn}$ (cassiterite, $\left.L_{\alpha}, 0.02\right)$ ), Sb (valentinite, $L_{\alpha}$, 0.01 ), Ba (sanbornite, $L_{\alpha}, 0.03$ ), Ta (simpsonite, $M_{\alpha}$, 0.04), W ( $\left.\mathrm{CaWO}_{4}, M_{\alpha}, 0.05\right), \mathrm{Pb}$ (mimetite, $M_{\alpha}, 0.04$ ), Bi (bismuthinite, $\left.M_{\beta}, 0.03\right)$, Th $\left(\mathrm{ThO}_{2}, M_{\alpha}, 0.04\right)$ and $\mathrm{U}$ (samarskite, $M_{\beta}, 0.05$ ). The results of the elements not listed in Tables $2-6$ are below the detection limits. All data were reduced using the PAP routine by Pouchou and Pichoir (1985).

\section{The Independencia Argentina pegmatite}

The dominant body of the IA pegmatite crops out with a maximum thickness of $30 \mathrm{~m}$ and along a strike length of $200 \mathrm{~m}$ with orientation $\mathrm{N} 35^{\circ}-40^{\circ} \mathrm{E}$ and dip $70^{\circ} \mathrm{W}$ (Fig. 3a-b). To the north, the pegmatite extends another $120 \mathrm{~m}$ with 1-2 $\mathrm{m}$ of thickness; to the south, a smaller dyke $50 \mathrm{~m}$ long by $2-3 \mathrm{~m}$ wide with the same attitude is displaced $10-15 \mathrm{~m}$ to the west (Fig. 3a). Further to the south, three additional segments crop out with average lengths and thicknesses of $45 \times 5,22 \times 3$ and $65 \times 5$ $\mathrm{m}$, respectively. Along these segments, the pegmatite is clearly boudinaged.

The IA pegmatite is internally zoned, symmetrically in the thinner parts and asymmetrically in the main body

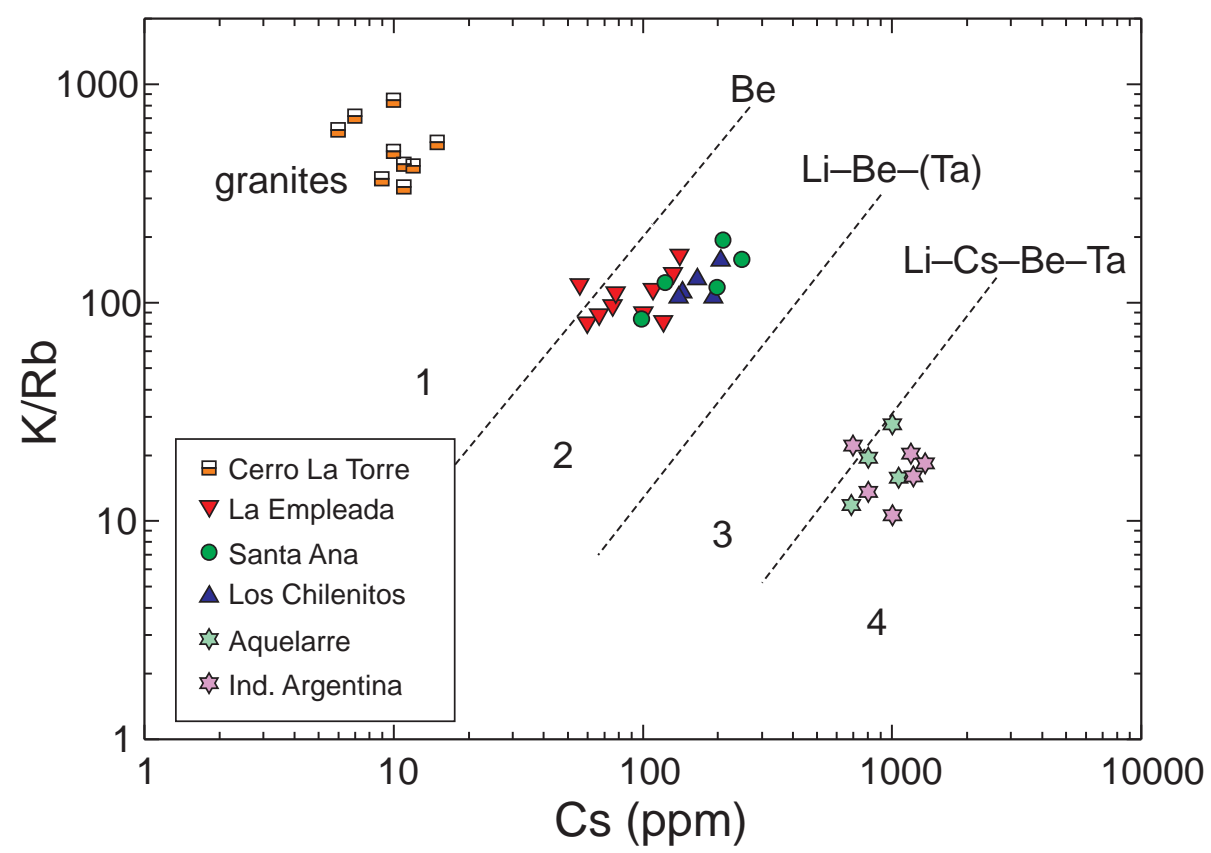




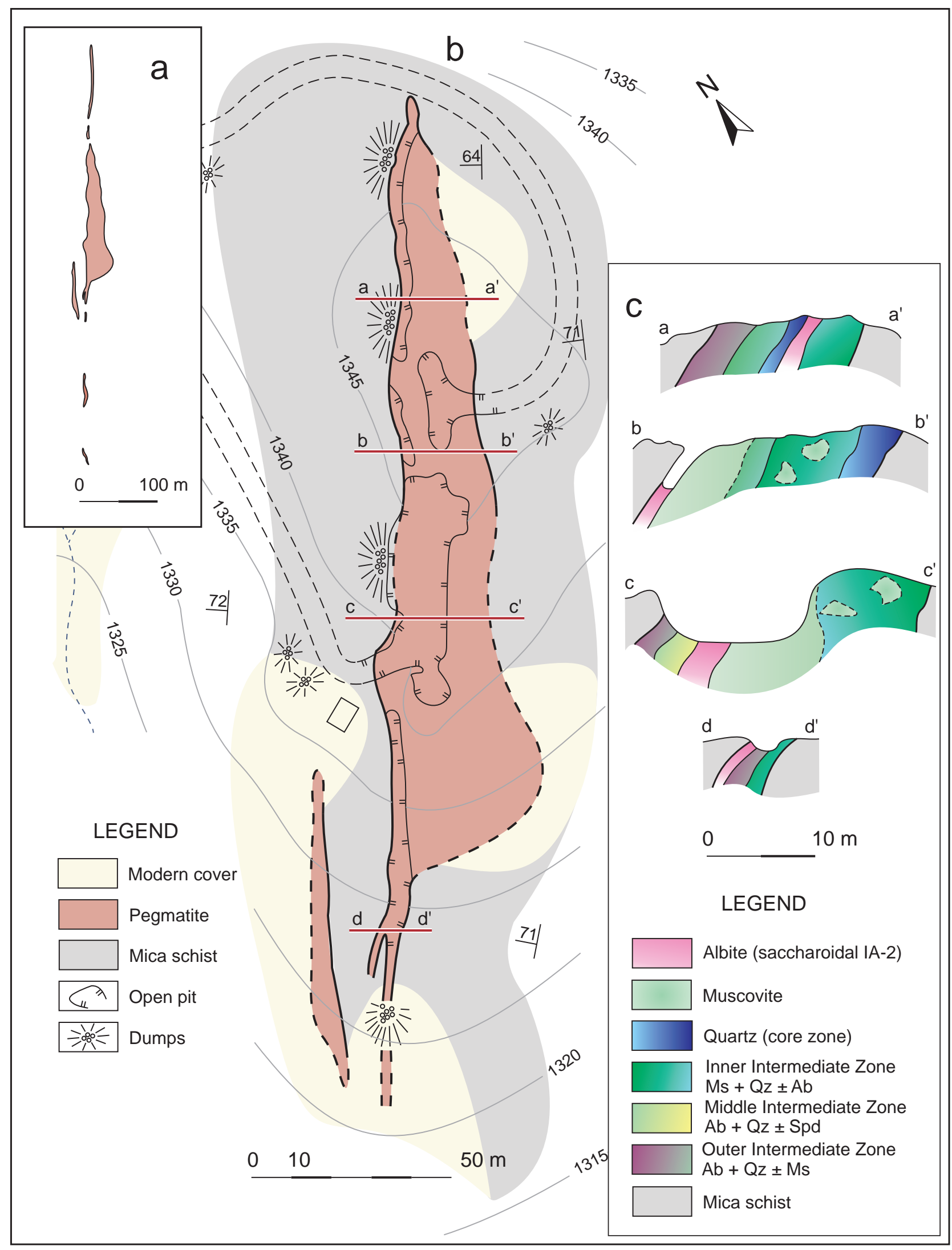

Fig. 3 Geological map of the Independencia Argentina pegmatite modified from Galliski et al. (1994): a - Distribution of the different segments of the pegmatite along the strike; $\mathbf{b}$ - Geological map of the main part of the pegmatite; $\mathbf{c}-$ Cross sections showing its zoning. 
where it consists of several zones: border, wall, outer intermediate, middle intermediate, inner intermediate, core and albite units (Fig. 3c). The zones are poorly defined, except for the albite unit, which has sharp contacts. The border zone is discontinuous, up to $5 \mathrm{~cm}$ thick, and is composed of fine-grained albite plus quartz with muscovite and fluorapatite as accessory minerals. The wall zone, up to $15 \mathrm{~cm}$ thick, is composed of coarse-grained albite plus quartz and has veinlets of grey quartz with platy albite. The outer intermediate zone, up to $3 \mathrm{~m}$ thick in the west side of the pegmatite, comprises $<1 \mathrm{~cm}$, pink, tabular albite crystals, two generations of quartz (primary and late as thin veinlets), and scarce muscovite in strained green sheets. The middle intermediate zone is only present in the central part of the pegmatite (c-c' profile, Fig. 3c) where it is defined by a fine-grained association of white mica and albite that replaces very few crystals of coarse-grained spodumene, set in a groundmass of albite and quartz. This unit is partially replaced by saccharoidal albite. The inner intermediate zone reaches considerable thickness and is composed mainly of muscovite and quartz in variable modal proportions. In its outer part, the inner intermediate zone is formed by a mass of fine-grained $(3-5 \mathrm{~cm})$ greenish muscovite with subordinate albite and quartz; inwards, quartz becomes more abundant and muscovite is disseminated or concentrated in irregular, fine-grained nodules 1-2 $\mathrm{m}$ in diameter, or meters-long blocks. The core zone is situated along the east side in most of the main portion of the pegmatite. It comprises massive quartz that grades, by increasing proportion of muscovite, to the inner intermediate zone. In the center of the core zone, irregular areas of $1-2 \mathrm{~m}^{2}$ with centripetal growths of tabular albite change inward to albite plus quartz plus columbite. In the other sections along the strike of the pegmatite, the position of the core zone is central and represents approximately one-third of the bulk volume.

The albite unit is formed mainly by saccharoidal, fine-grained $(<1 \mathrm{~mm})$ albite. It forms a tabular body, up to $3 \mathrm{~m}$ thick (Fig. 4a), as well as a few thinner veins or veinlets that crosscut other zones or rarely the host-rock (Fig. 4b-e). Where in contact with the quartz core, the albite unit can develop rims of slightly coarser albite (Fig. 4b) and can form a sort of ribbon texture by alternating bands of saccharoidal albite and quartz (Fig. 4c). Scarce secondary veinlets of quartz cut, in turn, the saccharoidal albite (Fig. 4c, upper right corner). Although the albite unit intrudes any of the other zones (Fig. 3c), it is thickest along the west side, close to the hanging wall of the pegmatite and, in parts, between the pegmatite and the host rock (Fig. 4a). The colour of the albite of this unit varies from white to pink or white with pink haloes around tiny inclusions of possible microlite(?). Accessory
Tab. 1 Whole-rock chemical composition of albite units

\begin{tabular}{|c|c|c|c|}
\hline Sample & IA-01 & IA-02 & IA-03 \\
\hline $\mathrm{SiO}_{2}$ wt. $\%$ & 67.50 & 68.10 & 68.30 \\
\hline $\mathrm{Al}_{2} \mathrm{O}_{3}$ & 19.80 & 19.80 & 19.90 \\
\hline $\mathrm{Fe}_{2} \mathrm{O}_{3}$ & 0.12 & 0.11 & 0.09 \\
\hline $\mathrm{MgO}$ & 0.06 & 0.06 & 0.06 \\
\hline $\mathrm{MnO}$ & $<0.01$ & $<0.01$ & $<0.01$ \\
\hline $\mathrm{CaO}$ & 0.15 & 0.07 & 0.10 \\
\hline $\mathrm{Na}_{2} \mathrm{O}$ & 11.40 & 11.40 & 11.30 \\
\hline $\mathrm{K}_{2} \mathrm{O}$ & 0.12 & 0.15 & 0.08 \\
\hline $\mathrm{P}_{2} \mathrm{O}_{5}$ & 0.23 & 0.12 & 0.16 \\
\hline LOI & 0.25 & 0.15 & 0.25 \\
\hline Total & 99.63 & 99.96 & 100.24 \\
\hline $\mathrm{Rb} \mathrm{ppm}$ & 14 & 15 & 13 \\
\hline $\mathrm{Sr}$ & 50 & 30 & 40 \\
\hline $\mathrm{Ba}$ & 10 & 8 & 12 \\
\hline $\mathrm{Nb}$ & $<10$ & 20 & 100 \\
\hline Y & $<10$ & $<10$ & $<10$ \\
\hline $\mathrm{Zr}$ & $<10$ & 20 & 30 \\
\hline \multicolumn{4}{|c|}{ CIPW normative composition (vol. \%) } \\
\hline Qtz & 0.58 & 1.07 & 2.12 \\
\hline $\mathrm{Ab}$ & 97.40 & 96.98 & 96.07 \\
\hline Or & 0.73 & 0.91 & 0.49 \\
\hline Co & 0.61 & 0.58 & 0.81 \\
\hline Hy & 0.21 & 0.20 & 0.19 \\
\hline $\mathrm{Mt}$ & 0.03 & 0.02 & 0.02 \\
\hline Ap & 0.44 & 0.23 & 0.30 \\
\hline ASI & 1.048 & 0.979 & 1.066 \\
\hline
\end{tabular}

wt. $\% \mathrm{TiO}_{2}$ and $\mathrm{Cr}_{2} \mathrm{O}_{3}$ less than 0.01

IA-01 massive platy albite (cleavelandite)

IA-02 white saccharoidal albite

IA-03 pink saccharoidal albite

minerals in the albite unit include irregularly distributed 1-2 cm, greenish blue fluorapatite crystals, associated with fine-grained columbite-group minerals, and scarce fine-grained muscovite flakes covering cracks or in tiny dispersed sheets. Some scarce thin veins of secondary $\mathrm{Qz}( \pm \mathrm{Ab})$ cross-cut the unit and have tapered, deformed and occasionally broken crystals of columbite in variable sizes, but commonly 1-2 cm across.

Bulk chemical analyses of the three types of albitedominated units give approximately the same values (in ppm) of $\mathrm{Rb}(15), \mathrm{Sr}(50), \mathrm{Ba}(10), \mathrm{Y}(<10)$, but variable $\mathrm{Nb}(<10,20,100)$ and $\mathrm{Zr}(<10,20$ and 30 , respectively) (Tab. 1). The content of $\mathrm{P}_{2} \mathrm{O}_{5}$ in the three varieties is 0.23 , 0.12 and 0.16 wt. $\%$.

The emplacement of the IA pegmatite was forcible and sub-concordant with the host mica schist. At the contact with the pegmatite, the mica schist has a meter-size aureole with spots of poikiloblastic biotite up to $2-3 \mathrm{~cm}$ long and others, smaller, of chlorite, both overprinted on the groundmass formed by $\mathrm{Qz}+\mathrm{Bt}+$ $\mathrm{Ms}+\mathrm{Pl}+\mathrm{Grt}+\mathrm{Chl}+$ ore minerals. It is not known whether this contact metamorphism was caused by the IA pegmatite, by its albite unit, or both. The pegmatite 


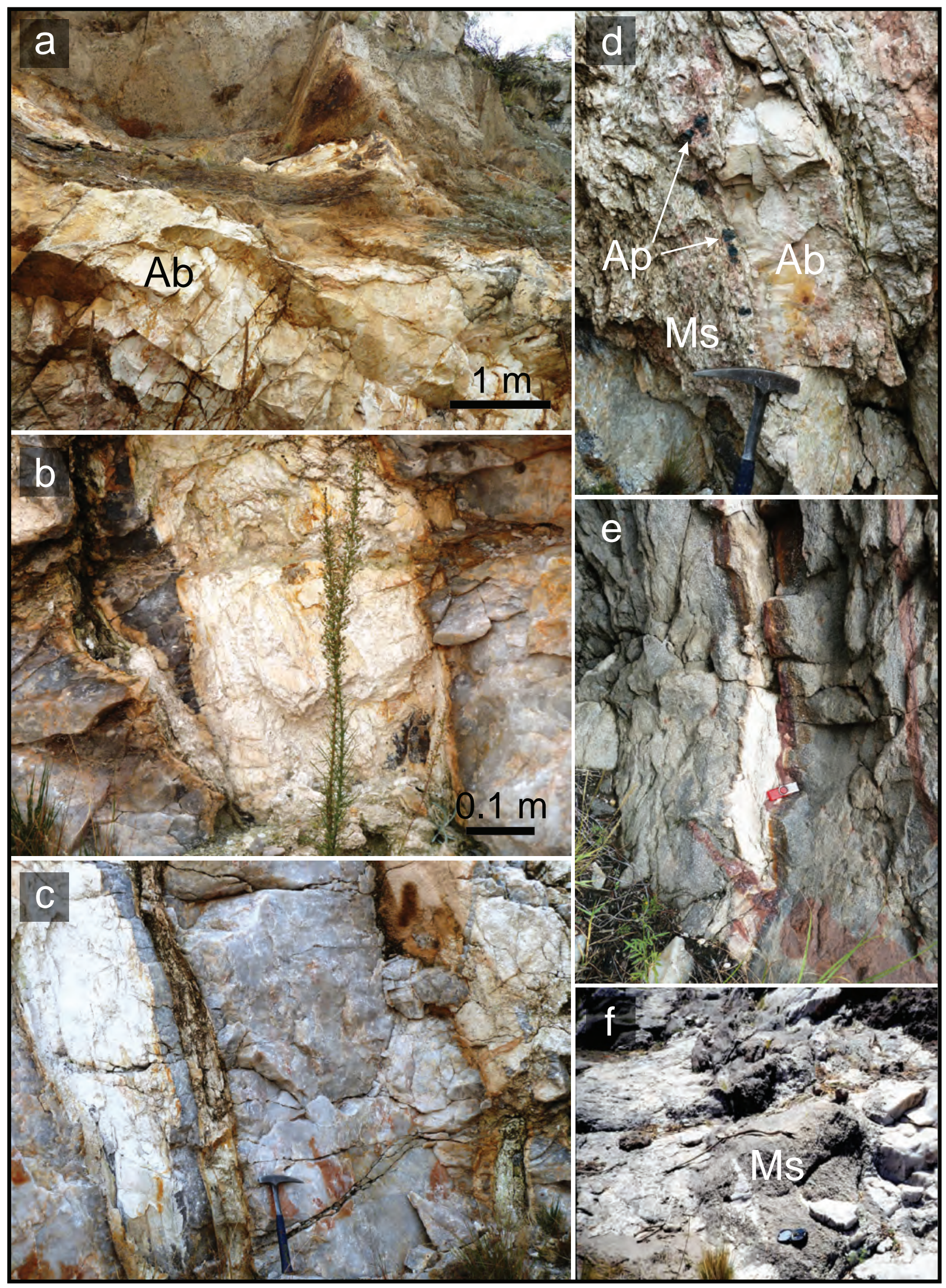


Tab. 2 Selected chemical compositions of albite (wt. \% and apfu based on $32 \mathrm{O}$ )

\begin{tabular}{|c|c|c|c|c|c|c|c|c|c|c|c|c|}
\hline \multirow[b]{2}{*}{ Analysis } & \multicolumn{4}{|c|}{ Tabular (clevelandite) } & \multicolumn{4}{|c|}{ Saccharoidal pink } & \multicolumn{4}{|c|}{ Saccharoidal white } \\
\hline & 10 & 11 & 12 & 13 & 17 & 19 & 20 & 21 & 7 & 22 & 23 & 24 \\
\hline $\mathrm{SiO}_{2}$ & 68.58 & 68.77 & 68.94 & 68.98 & 68.26 & 68.41 & 69.37 & 68.21 & 68.55 & 68.48 & 67.95 & 67.87 \\
\hline $\mathrm{Al}_{2} \mathrm{O}_{3}$ & 19.60 & 19.68 & 19.61 & 19.84 & 19.83 & 19.85 & 19.83 & 20.10 & 19.89 & 19.42 & 19.42 & 19.36 \\
\hline $\mathrm{MgO}$ & 0.00 & 0.03 & 0.01 & 0.00 & 0.02 & 0.00 & 0.00 & 0.01 & 0.00 & 0.00 & 0.00 & 0.02 \\
\hline $\mathrm{FeO}$ & 0.04 & 0.03 & 0.00 & 0.03 & 0.04 & 0.00 & 0.00 & 0.02 & 0.00 & 0.00 & 0.07 & 0.02 \\
\hline $\mathrm{CaO}$ & 0.07 & 0.04 & 0.03 & 0.03 & 0.03 & 0.02 & 0.02 & 0.04 & 0.00 & 0.05 & 0.01 & 0.02 \\
\hline $\mathrm{Na}_{2} \mathrm{O}$ & 11.05 & 11.37 & 11.00 & 11.09 & 11.06 & 11.02 & 11.16 & 11.12 & 11.45 & 11.16 & 10.98 & 11.27 \\
\hline $\mathrm{K}_{2} \mathrm{O}$ & 0.08 & 0.08 & 0.11 & 0.10 & 0.10 & 0.08 & 0.07 & 0.10 & 0.07 & 0.10 & 0.07 & 0.08 \\
\hline Total & 99.42 & 100.00 & 99.70 & 100.07 & 99.34 & 99.38 & 100.45 & 99.60 & 99.96 & 99.21 & 98.50 & 98.64 \\
\hline $\mathrm{Si}$ & 12.012 & 11.991 & 12.033 & 12.002 & 11.971 & 11.984 & 12.019 & 11.935 & 11.960 & 12.025 & 12.013 & 11.998 \\
\hline $\mathrm{Al}$ & 4.043 & 4.041 & 4.031 & 4.065 & 4.096 & 4.095 & 4.046 & 4.142 & 4.087 & 4.016 & 4.043 & 4.030 \\
\hline $\mathrm{Mg}$ & 0.000 & 0.008 & 0.003 & 0.000 & 0.005 & 0.000 & 0.000 & 0.003 & 0.000 & 0.000 & 0.000 & 0.005 \\
\hline $\mathrm{Fe}^{2+}$ & 0.006 & 0.004 & 0.000 & 0.004 & 0.006 & 0.000 & 0.000 & 0.003 & 0.000 & 0.000 & 0.010 & 0.003 \\
\hline $\mathrm{Ca}$ & 0.013 & 0.007 & 0.006 & 0.006 & 0.006 & 0.004 & 0.004 & 0.007 & 0.000 & 0.009 & 0.002 & 0.004 \\
\hline $\mathrm{Na}$ & 3.753 & 3.844 & 3.723 & 3.741 & 3.761 & 3.743 & 3.749 & 3.773 & 3.873 & 3.800 & 3.764 & 3.863 \\
\hline $\mathrm{K}$ & 0.018 & 0.018 & 0.024 & 0.022 & 0.022 & 0.018 & 0.015 & 0.022 & 0.016 & 0.022 & 0.016 & 0.018 \\
\hline$\Sigma$ Cat. & 19.845 & 19.913 & 19.820 & 19.840 & 19.867 & 19.844 & 19.833 & 19.885 & 19.936 & 19.872 & 19.848 & 19.921 \\
\hline Ab vol. \% & 99.2 & 99.3 & 99.2 & 99.2 & 99.2 & 99.4 & 99.5 & 99.2 & 99.6 & 99.2 & 99.5 & 99.4 \\
\hline An & 0.3 & 0.2 & 0.2 & 0.2 & 0.2 & 0.1 & 0.1 & 0.2 & 0 & 0.2 & 0.1 & 0.1 \\
\hline Or & 0.5 & 0.5 & 0.6 & 0.6 & 0.6 & 0.5 & 0.4 & 0.6 & 0.4 & 0.6 & 0.4 & 0.5 \\
\hline
\end{tabular}

$\mathrm{Sr}$ and Ba sought but not detected

also developed a thin microscopic tourmalinization halo in the mica schist. The pegmatite shows clear structural and textural evidence of reactivation, strain and synkinematic crystallization, especially during the formation of the albite unit.

\section{Mineralogy}

\subsection{Albite}

Albite, in tabular and saccharoidal textural varieties, is the most abundant mineral in the IA pegmatite. Tabular albite occurs in $2-3 \mathrm{~cm}$ long, white or pink crystals, in monomineralic aggregates or associated with quartz or muscovite. These tabular crystals are frequently curved and, in the vicinity of the pegmatite core, form groups associated with quartz and columbite. This kind of albite

Fig. 4a - Saccharoidal albite unit $(\mathrm{Ab})$ intruded between other zones of the IA pegmatite and the host rock. Note the spots of biotite produced by the contact metamorphism. b - Saccharoidal albite (white) crosscutting the quartz core (grey) and partly replacing it at the contact. c - Saccharoidal albite (white) replacing quartz (grey) of the core in several subparallel veins. Some albite veins are sheared. In the upper right corner of the image, a veinlet of quartz crosscuts the albite unit. d - Vein of saccharoidal albite (white) cutting an assemblage of muscovite + albite (beige); note metasomatic crystals of fluorapatite (Ap) along the contact. $\mathbf{e}$ - Veinlet of saccharoidal albite (white) intruding the host mica schist (grey); the grain size of mica increases with proximity to the contact, especially on the left side of this image; the USB drive for scale is $5 \mathrm{~cm}$ long. $\mathbf{f}$ - Elongated blocks of fine-grained muscovite (Ms) included in the quartz core. also occurs in small cavities as clear crystals with terminal faces and a multiplicity of fluid-inclusion associations. The saccharoidal albite makes up the bulk of the albite unit in friable aggregates of almost pure, irregularly rounded, white or pink grains $<1 \mathrm{~mm}$ in diameter. It is associated with $<3 \%$ fluorapatite, columbite, muscovite and microlite(?). The EMPA chemical composition (Tab. 2) of the two varieties of albite is quite uniform with $\mathrm{Ab}_{99.1-99.6}$.

\subsection{Quartz}

Quartz occurs mainly as massive, milky, coarse-grained fractured grains. Small amounts of quartz are associated with tabular albite or develop veinlets or very small pockets; in both cases the crystals can be euhedral and have growth shadows marked by planar accumulations of fluid-inclusion associations. The quartz of the core zone is cut by albite or partially replaced by a rim of light brownish-pink albite where it is in contact with the saccharoidal albite unit (Fig. 4b).

\subsection{Muscovite}

Muscovite is very abundant in the transition between the inner intermediate zone and the core, disseminated in the quartz core, and forming massive, meter-sized aggregates in quartz (Fig. 4f). Muscovite is also associated with saccharoidal albite or quartz in late veinlets that crosscut the other zones. A third occurrence consists of an aphanitic association with a variable quantity of 
Tab. 3 Chemical composition of muscovite (wt. \% and apfu based on $24(\mathrm{O}, \mathrm{OH}, \mathrm{F}, \mathrm{Cl})$ )

\begin{tabular}{|c|c|c|c|c|c|c|}
\hline Sample & IA1-1 & IA1-2 & IA 1-3 & IA1-4 & IA1-5 & IA1-6 \\
\hline$\overline{\mathrm{SiO}_{2}}$ & 46.09 & 45.94 & 45.66 & 45.30 & 45.95 & 46.43 \\
\hline $\mathrm{TiO}_{2}$ & 0.01 & 0.04 & 0.04 & 0.14 & 0.03 & 0.05 \\
\hline $\mathrm{Al}_{2} \mathrm{O}_{3}$ & 38.32 & 38.58 & 38.71 & 39.01 & 38.70 & 38.92 \\
\hline $\mathrm{FeO}$ & 0.49 & 0.46 & 0.51 & 0.35 & 0.42 & 0.52 \\
\hline $\mathrm{MnO}$ & 0.04 & 0.02 & 0.02 & 0.00 & 0.05 & 0.00 \\
\hline $\mathrm{CaO}$ & 0.00 & 0.02 & 0.00 & 0.00 & 0.01 & 0.03 \\
\hline $\mathrm{Na}_{2} \mathrm{O}$ & 0.77 & 0.85 & 0.76 & 0.53 & 0.68 & 0.59 \\
\hline $\mathrm{K}_{2} \mathrm{O}$ & 9.69 & 9.58 & 9.84 & 9.68 & 9.63 & 9.48 \\
\hline $\mathrm{F}$ & 0.05 & 0.00 & 0.05 & 0.00 & 0.00 & 0.00 \\
\hline $\mathrm{Cl}$ & 0.08 & 0.06 & 0.06 & 0.07 & 0.04 & 0.05 \\
\hline $\mathrm{H}_{2} \mathrm{O}$ & 4.52 & 4.55 & 4.52 & 4.53 & 4.56 & 4.59 \\
\hline$-\mathrm{O}=\mathrm{F}=\mathrm{Cl}$ & -0.04 & -0.01 & -0.03 & -0.02 & -0.01 & -0.01 \\
\hline Total & 100.02 & 100.09 & 100.14 & 99.59 & 100.06 & 100.65 \\
\hline$\overline{\mathrm{Si}}$ & 6.060 & 6.033 & 6.005 & 5.976 & 6.032 & 6.050 \\
\hline${ }^{\mathrm{IV}} \mathrm{Al}$ & 1.940 & 1.967 & 1.995 & 2.024 & 1.968 & 1.950 \\
\hline Sum IV & 8.000 & 8.000 & 8.000 & 8.000 & 8.000 & 8.000 \\
\hline${ }^{\mathrm{vI}} \mathrm{Al}$ & 3.993 & 3.999 & 4.000 & 4.036 & 4.015 & 4.022 \\
\hline $\mathrm{Ti}$ & 0.001 & 0.004 & 0.004 & 0.014 & 0.003 & 0.005 \\
\hline $\mathrm{Fe}^{2+}$ & 0.054 & 0.051 & 0.056 & 0.039 & 0.046 & 0.057 \\
\hline $\mathrm{Mn}$ & 0.004 & 0.002 & 0.002 & 0.000 & 0.006 & 0.000 \\
\hline $\mathrm{Ca}$ & 0.000 & 0.003 & 0.000 & 0.000 & 0.001 & 0.004 \\
\hline $\mathrm{Na}$ & 0.196 & 0.216 & 0.194 & 0.136 & 0.173 & 0.149 \\
\hline$\underline{\mathrm{K}}$ & 1.625 & 1.605 & 1.651 & 1.629 & 1.613 & 1.576 \\
\hline$\Sigma$ Cat. & 21.873 & 21.880 & 21.907 & 21.854 & 21.857 & 21.813 \\
\hline$\overline{\mathrm{CF}}$ & 0.042 & 0.000 & 0.042 & 0.000 & 0.000 & 0.000 \\
\hline $\mathrm{CCl}$ & 0.036 & 0.027 & 0.027 & 0.031 & 0.018 & 0.022 \\
\hline $\mathrm{OH}$ & 3.961 & 3.987 & 3.966 & 3.984 & 3.991 & 3.989 \\
\hline $\mathrm{O}$ & 24.000 & 24.000 & 24.000 & 24.000 & 24.000 & 24.000 \\
\hline
\end{tabular}

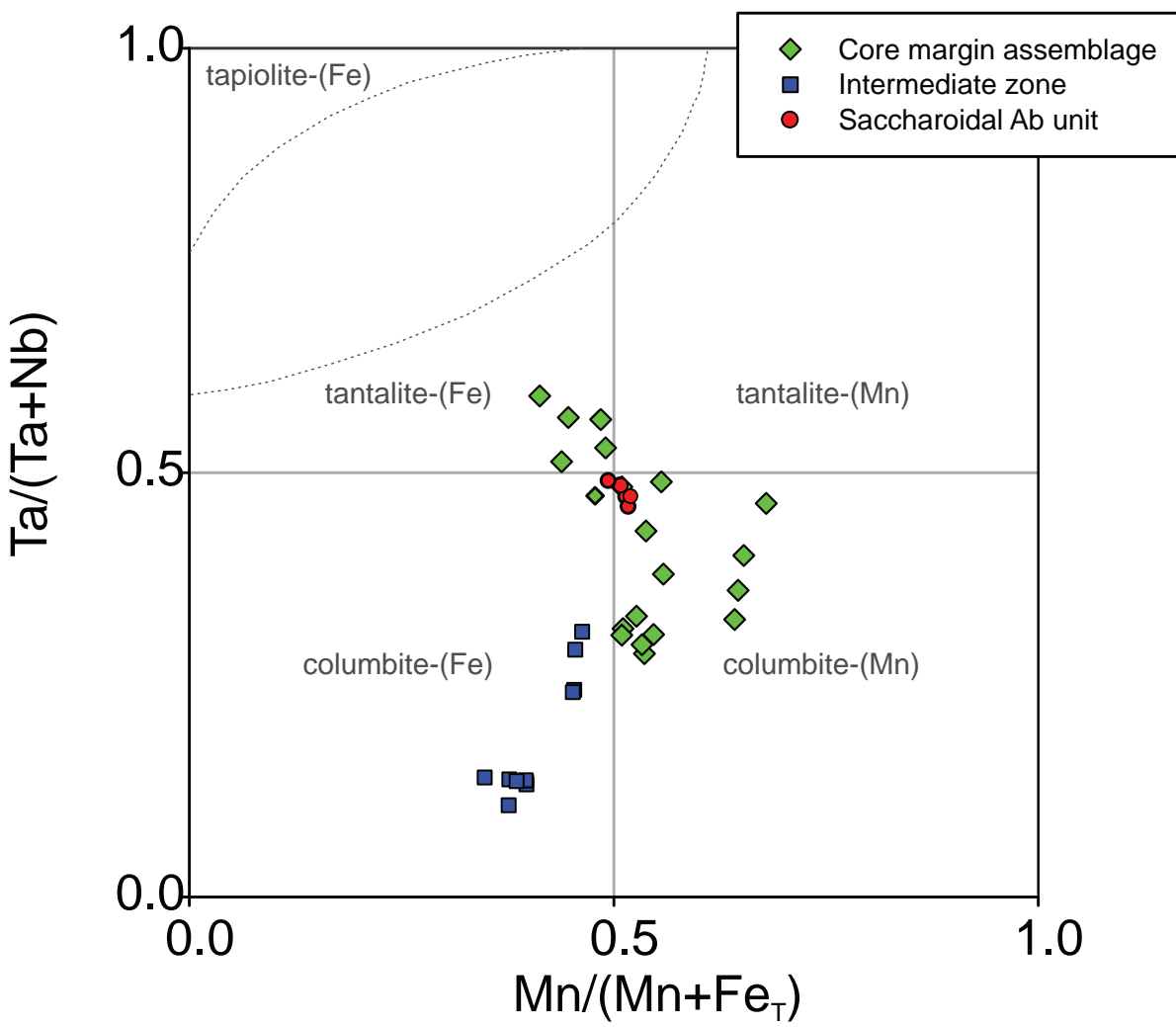

albite replacing earlier formed minerals. The association of muscovite with albite and columbite is common. The powder $\mathrm{X}$-ray diffractograms indicate that the predominant polytype is 2M1. The chemical analyses of muscovite show rather uniform compositions with low contents of $\mathrm{Na}_{2} \mathrm{O}$ and $\mathrm{FeO}$ (Tab. 3).

\subsection{Microcline}

Microcline occurs in the middle and inner intermediate zones as scarce, dm-sized, perthitic, gray twinned crystals, partially replaced by tabular albite and muscovite. Its content of Cs (up to $1310 \mathrm{ppm}$ ) is the highest detected in microcline of the Cerro La Torre pegmatite group (Fig. 2).

\subsection{Spodumene}

In the middle intermediate zone, rare prismatic pseudomorphs after spodumene crystals up to $0.6 \mathrm{~m}$ long are totally replaced by a fine-grained greenish white association of muscovite + albite.

\subsection{Columbite-group minerals}

Minerals of the columbite group are widespread in the IA pegmatite. They form $\mathrm{cm}$-sized crystals associated with tabular albite in pods that occasionally contain small cavities with quartz or albite crystals; these pods are usually located in the internal parts of the inner in-

Fig. 5 Composition of columbite-group minerals from the IA pegmatite (apfu) in the columbite quadrilateral. The fields corresponding to tapiolite-( $\mathrm{Fe})$, tantalite-(Fe), tantalite-(Mn), columbite-( $\mathrm{Fe})$ and columbite-( $\mathrm{Mn})$ are taken from Černý et al. (1992). 
Tab. 4 Selected chemical compositions of columbite-group minerals (wt. \% and apfu based on $24 \mathrm{O}$ )

\begin{tabular}{|c|c|c|c|c|c|c|c|c|c|c|}
\hline \multirow{2}{*}{$\begin{array}{l}\text { Sample } \\
\text { Point }\end{array}$} & \multicolumn{3}{|c|}{ IA2 } & \multicolumn{4}{|c|}{ IA9 } & \multicolumn{3}{|c|}{ IA10 } \\
\hline & & & & A1 & A3 & A4 & B1 & B4 & B6 & D3 \\
\hline Analysis & 1 & 2 & 3 & 9 & 11 & 12 & 18 & 36 & 38 & 47 \\
\hline $\mathrm{WO}_{3}$ & 1.86 & 1.84 & 1.63 & 0.00 & 0.00 & 0.00 & 0.00 & 0.08 & 0.05 & 0.48 \\
\hline $\mathrm{Nb}_{2} \mathrm{O}_{5}$ & 31.85 & 30.86 & 30.96 & 24.46 & 26.21 & 48.44 & 46.88 & 64.03 & 63.74 & 52.76 \\
\hline $\mathrm{Ta}_{2} \mathrm{O}_{5}$ & 47.15 & 48.40 & 48.34 & 58.62 & 56.16 & 32.35 & 34.74 & 16.96 & 16.76 & 27.88 \\
\hline $\mathrm{TiO}_{2}$ & 0.55 & 0.74 & 0.72 & 0.98 & 0.73 & 0.07 & 0.05 & 0.60 & 0.53 & 0.65 \\
\hline $\mathrm{Sc}_{2} \mathrm{O}_{3}$ & 0.09 & 0.12 & 0.09 & 0.00 & 0.00 & 0.00 & 0.00 & 0.00 & 0.00 & 0.00 \\
\hline $\mathrm{Bi}_{2} \mathrm{O}_{3}$ & 0.13 & 0.08 & 0.00 & 0.00 & 0.00 & 0.00 & 0.00 & 0.00 & 0.00 & 0.00 \\
\hline $\mathrm{MgO}$ & 0.01 & 0.00 & 0.00 & 0.07 & 0.00 & 0.00 & 0.00 & 0.05 & 0.02 & 0.02 \\
\hline $\mathrm{MnO}$ & 9.09 & 8.72 & 8.65 & 6.73 & 7.88 & 9.77 & 9.31 & 7.93 & 7.71 & 8.55 \\
\hline $\mathrm{FeO}$ & 6.36 & 7.10 & 7.28 & 7.34 & 7.65 & 6.91 & 5.47 & 9.87 & 9.64 & 8.54 \\
\hline $\mathrm{PbO}$ & 0.10 & 0.07 & 0.14 & 0.00 & 0.00 & 0.00 & 0.00 & 0.00 & 0.00 & 0.00 \\
\hline Total & 99.87 & 99.64 & 99.18 & 99.62 & 99.14 & 98.41 & 98.35 & 100.82 & 99.96 & 99.95 \\
\hline $\bar{W}$ & 0.134 & 0.133 & 0.119 & 0.000 & 0.000 & 0.000 & 0.000 & 0.005 & 0.003 & 0.031 \\
\hline $\mathrm{Nb}$ & 3.994 & 3.906 & 3.942 & 3.178 & 3.429 & 5.675 & 5.477 & 6.787 & 6.792 & 5.939 \\
\hline $\mathrm{Ta}$ & 3.556 & 3.685 & 3.702 & 4.582 & 4.419 & 2.280 & 2.441 & 1.084 & 1.074 & 1.889 \\
\hline $\mathrm{Ti}$ & 0.115 & 0.156 & 0.152 & 0.212 & 0.159 & 0.014 & 0.010 & 0.106 & 0.094 & 0.122 \\
\hline $\mathrm{Sn}$ & 0.011 & 0.009 & 0.007 & 0.021 & 0.005 & 0.000 & 0.000 & 0.005 & 0.003 & 0.003 \\
\hline $\mathrm{Sc}$ & 0.022 & 0.029 & 0.022 & 0.000 & 0.000 & 0.000 & 0.000 & 0.000 & 0.000 & 0.000 \\
\hline $\mathrm{Bi}$ & 0.009 & 0.006 & 0.000 & 0.000 & 0.000 & 0.000 & 0.000 & 0.000 & 0.000 & 0.000 \\
\hline $\mathrm{Mg}$ & 0.004 & 0.000 & 0.000 & 0.030 & 0.000 & 0.000 & 0.000 & 0.017 & 0.007 & 0.007 \\
\hline $\mathrm{Mn}$ & 2.135 & 2.066 & 2.058 & 1.638 & 1.931 & 2.145 & 2.038 & 1.573 & 1.539 & 1.802 \\
\hline $\mathrm{Fe}^{2+}$ & 1.475 & 1.662 & 1.709 & 2.062 & 1.965 & 1.686 & 1.593 & 2.179 & 2.192 & 1.994 \\
\hline $\mathrm{Pb}$ & 0.007 & 0.005 & 0.011 & 0.000 & 0.000 & 0.000 & 0.000 & 0.000 & 0.000 & 0.000 \\
\hline $\mathrm{Fe}^{3+}$ & 0.538 & 0.343 & 0.278 & 0.269 & 0.103 & 0.169 & 0.369 & 0.220 & 0.262 & 0.194 \\
\hline $\mathrm{Ta} \#[\mathrm{Ta} /(\mathrm{Ta}+\mathrm{Nb})]$ & 0.47 & 0.49 & 0.48 & 0.59 & 0.56 & 0.29 & 0.31 & 0.14 & 0.14 & 0.24 \\
\hline $\mathrm{Mn} \#\left[\mathrm{Mn} /\left(\mathrm{Mn}+\mathrm{Fe}_{\mathrm{T}}\right)\right]$ & 0.51 & 0.51 & 0.51 & 0.41 & 0.48 & 0.54 & 0.51 & 0.40 & 0.39 & 0.45 \\
\hline
\end{tabular}

termediate zone. Tabular columbite crystals frequently are crosscut by fractures filled by quartz or platy albite. Columbite in the albite pods shows zoning, with increasing values of $\mathrm{Ta} \#[\mathrm{Ta} /(\mathrm{Ta}+\mathrm{Nb})]$ and minor variation in $\mathrm{Mn} \#\left[\mathrm{Mn} /\left(\mathrm{Mn}+\mathrm{Fe}_{\mathrm{T}}\right)\right]$ (Tab. 4) with evolving fractionation. Another form of columbite composes thick tabular crystals in quartz veins that crosscut the outer part of the quartz core or the inner intermediate zone. These crystals have variable chemical compositions with zoning, occasionally oscillatory, between tantalite-( $\mathrm{Fe})$ and columbite-(Mn) (Tab. 4, Figs $5,6 a)$. Columbite-group minerals also form mm-sized platy crystals randomly disseminated in saccharoidal albite, locally associated with fluorapatite and irregularly concentrated in cm-

Fig. 6a - Back-scattered electron image of columbite-group minerals from the intermediate zone showing a complex zoning pattern. b - Photograph of the columbite-group minerals from the saccharoidal albite unit.
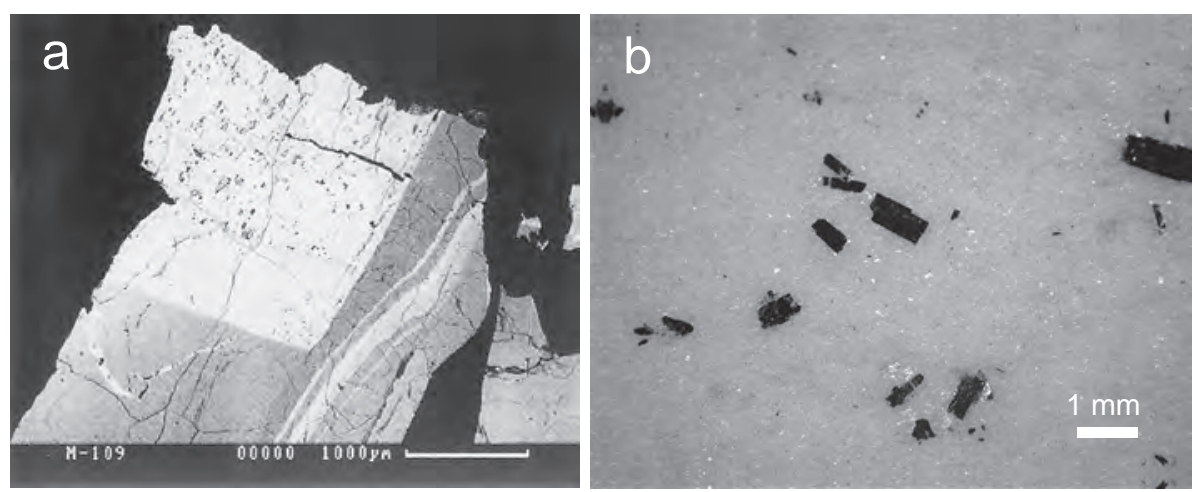

sized areas. These crystals have a fairly homogeneous chemical composition corresponding dominantly to columbite-(Mn) with Ta\# and Mn\# very close to 0.50 (Tab. 4, Figs 5, 6b).

\subsection{Fluorapatite}

Fluorapatite is a frequent accessory phase throughout the pegmatite, especially in the saccharoidal albite unit. It occurs as disseminated rounded bluish grains usually as- 
Tab. 5 Chemical composition of fluorapatite in sample IA-1 (wt. \% and apfu based on 13 anions)

\begin{tabular}{|c|c|c|c|c|c|c|c|c|c|c|c|c|}
\hline Point & 1 & 2 & 3 & 4 & 5 & 6 & 26 & 27 & 28 & 29 & 30 & 31 \\
\hline $\mathrm{P}_{2} \mathrm{O}_{5}$ & 42.49 & 42.18 & 42.25 & 42.45 & 41.21 & 42.54 & 42.92 & 42.94 & 41.65 & 42.52 & 42.82 & 42.46 \\
\hline $\mathrm{SiO}_{2}$ & 0.03 & 0.02 & 0.04 & 0.04 & 0.03 & 0.05 & 0.00 & 0.00 & 0.00 & 0.02 & 0.00 & 0.00 \\
\hline $\mathrm{Al}_{2} \mathrm{O}_{3}$ & 0.03 & 0.00 & 0.03 & 0.00 & 0.02 & 0.01 & 0.00 & 0.00 & 0.00 & 0.01 & 0.00 & 0.05 \\
\hline $\mathrm{MnO}$ & 3.00 & 3.07 & 2.89 & 2.93 & 2.96 & 3.10 & 2.43 & 2.68 & 2.67 & 2.42 & 1.32 & 2.72 \\
\hline $\mathrm{FeO}$ & 0.32 & 0.23 & 0.28 & 0.24 & 0.27 & 0.19 & 0.16 & 0.23 & 0.23 & 0.15 & 0.07 & 0.19 \\
\hline $\mathrm{CaO}$ & 50.95 & 50.06 & 49.55 & 49.98 & 50.25 & 50.48 & 52.56 & 51.64 & 51.56 & 51.26 & 52.85 & 52.14 \\
\hline $\mathrm{ZnO}$ & 0.00 & 0.01 & 0.10 & 0.00 & 0.04 & 0.00 & 0.00 & 0.00 & 0.00 & 0.00 & 0.00 & 0.07 \\
\hline $\mathrm{SrO}$ & 0.00 & 0.00 & 0.00 & 0.00 & 0.00 & 0.00 & 0.00 & 0.04 & 0.11 & 0.00 & 0.36 & 0.00 \\
\hline $\mathrm{F}$ & 3.44 & 3.48 & 3.29 & 3.34 & 3.49 & 2.96 & 2.91 & 2.80 & 2.91 & 2.76 & 3.21 & 2.73 \\
\hline $\mathrm{Cl}$ & 0.00 & 0.00 & 0.00 & 0.00 & 0.00 & 0.00 & 0.00 & 0.00 & 0.01 & 0.07 & 0.00 & 0.01 \\
\hline $\mathrm{H}_{2} \mathrm{O} *$ & 0.14 & 0.10 & 0.18 & 0.17 & 0.07 & 0.36 & 0.41 & 0.46 & 0.37 & 0.44 & 0.26 & 0.48 \\
\hline$-\mathrm{O}=\mathrm{F}$ & -1.45 & -1.47 & -1.39 & -1.41 & -1.47 & -1.25 & -1.23 & -1.18 & -1.23 & -1.16 & -1.35 & -1.15 \\
\hline$-\mathrm{O}=\mathrm{Cl}$ & 0.00 & 0.00 & 0.00 & 0.00 & 0.00 & 0.00 & 0.00 & 0.00 & 0.00 & -0.02 & 0.00 & 0.00 \\
\hline $\mathrm{P}$ & 3.049 & 3.062 & 3.075 & 3.074 & 3.030 & 3.061 & 3.041 & 3.055 & 3.021 & 3.057 & 3.049 & 3.029 \\
\hline $\mathrm{Si}$ & 0.003 & 0.002 & 0.003 & 0.003 & 0.003 & 0.004 & 0.000 & 0.000 & 0.000 & 0.002 & 0.000 & 0.000 \\
\hline $\mathrm{Al}$ & 0.003 & 0.000 & 0.003 & 0.000 & 0.002 & 0.001 & 0.000 & 0.000 & 0.000 & 0.001 & 0.000 & 0.005 \\
\hline $\mathrm{Mn}^{2+}$ & 0.215 & 0.223 & 0.210 & 0.212 & 0.218 & 0.223 & 0.172 & 0.191 & 0.194 & 0.174 & 0.094 & 0.194 \\
\hline $\mathrm{Fe}^{2+}$ & 0.023 & 0.016 & 0.020 & 0.017 & 0.020 & 0.014 & 0.011 & 0.016 & 0.016 & 0.011 & 0.005 & 0.013 \\
\hline $\mathrm{Ca}$ & 4.629 & 4.600 & 4.564 & 4.580 & 4.676 & 4.599 & 4.714 & 4.650 & 4.733 & 4.666 & 4.764 & 4.708 \\
\hline $\mathrm{Zn}$ & 0.000 & 0.001 & 0.006 & 0.000 & 0.003 & 0.000 & 0.000 & 0.000 & 0.000 & 0.000 & 0.000 & 0.004 \\
\hline $\mathrm{Sr}^{2+}$ & 0.000 & 0.000 & 0.000 & 0.000 & 0.000 & 0.000 & 0.000 & 0.002 & 0.005 & 0.000 & 0.018 & 0.000 \\
\hline $\mathrm{F}^{-}$ & 0.922 & 0.944 & 0.895 & 0.903 & 0.959 & 0.796 & 0.770 & 0.744 & 0.788 & 0.741 & 0.853 & 0.727 \\
\hline $\mathrm{Cl}^{-}$ & 0.000 & 0.000 & 0.000 & 0.000 & 0.000 & 0.000 & 0.000 & 0.000 & 0.001 & 0.010 & 0.000 & 0.001 \\
\hline $\mathrm{H}^{+}$ & 0.078 & 0.056 & 0.105 & 0.097 & 0.041 & 0.204 & 0.230 & 0.256 & 0.210 & 0.249 & 0.147 & 0.271 \\
\hline $\mathrm{O}^{2-}$ & 12.078 & 12.056 & 12.105 & 12.097 & 12.041 & 12.204 & 12.230 & 12.256 & 12.210 & 12.249 & 12.147 & 12.271 \\
\hline$\Sigma$ & 7.922 & 7.904 & 7.881 & 7.886 & 7.952 & 7.902 & 7.939 & 7.914 & 7.969 & 7.911 & 7.930 & 7.953 \\
\hline
\end{tabular}

$\mathrm{H}_{2} \mathrm{O}^{*}$ content was calculated assuming $1(\mathrm{OH}, \mathrm{F}, \mathrm{Cl})$ apfu

sociated with columbite in domains where both minerals are more abundant than in surrounding material. Fluorapatite also occurs as $\sim 1 \mathrm{~cm}$ crystals included in quartz at the periphery of the core zone. Lastly, it formed as a secondary mineral in the selvages of some saccharoidal albite veins (Fig. 4d). All of the analyzed crystals have a chemical composition that corresponds to fluorapatite fairly enriched in $\mathrm{Mn}$ (up to $3.10 \mathrm{wt}$. \% $\mathrm{MnO}$ or 0.223 Mn apfu, Tab. 5).

\subsection{Spessartine}

Rare aggregates of euhedral mm-sized crystals of spessartine are found in the zones with fine-grained muscovite. Their chemical composition is fairly homogeneous, averaging $\operatorname{Sps}_{74.4} \operatorname{Alm}_{24.5} \operatorname{Adr}_{0.9} \operatorname{Prp}_{0.2}$ (Tab. 6, Fig. 7).

\subsection{Beryl}

A few crystals of beryl were found in samples taken from the dumps of the IA pegmatite. Euhedral yellowish green prisms up to $5 \mathrm{~cm}$ long are commonly partially replaced by an assemblage of $\mathrm{Ms}+\mathrm{Ab}$.

\subsection{Microlite (?)}

A very few, fine-grained $(<1 \mathrm{~mm})$, equant crystals of a transparent light yellow, isotropic mineral with refraction index $>1.78$ were found dispersed in the saccharoidal albite. These grains are accompanied by a light pink halo in adjacent minerals.

\subsection{Rutile}

Rutile occurs as acicular microscopic crystals, included in secondary quartz veinlets that crosscut microcline and albite of the intermediate zone.

\subsection{Bismuth}

This mineral is present as common, $<100 \mu \mathrm{m}$, rounded inclusions in cm-sized crystals of columbite from the albite replacement zone. Its identity was confirmed by EMPA. 
Tab. 6 Chemical composition of garnet (wt. \% and apfu based on $24 \mathrm{O}$ and 16 cations)

\begin{tabular}{|c|c|c|c|c|c|c|c|c|c|c|c|}
\hline \multirow{2}{*}{$\begin{array}{l}\text { Sample } \\
\text { Analysis }\end{array}$} & \multicolumn{5}{|c|}{ IA-1 } & \multicolumn{6}{|c|}{ IA-2 } \\
\hline & 1 & 2 & 3 & 4 & 5 & 1 & 2 & 3 & 4 & 5 & 6 \\
\hline $\mathrm{SiO}_{2}$ & 35.05 & 35.46 & 35.66 & 35.12 & 35.36 & 36.54 & 36.50 & 36.59 & 36.63 & 36.48 & 36.49 \\
\hline $\mathrm{TiO}_{2}$ & 0.12 & 0.09 & 0.05 & 0.08 & 0.06 & 0.09 & 0.05 & 0.02 & 0.06 & 0.06 & 0.02 \\
\hline $\mathrm{Al}_{2} \mathrm{O}_{3}$ & 20.87 & 20.78 & 20.98 & 20.67 & 20.91 & 21.05 & 21.08 & 21.17 & 21.25 & 21.25 & 21.04 \\
\hline $\mathrm{FeO}$ & 10.88 & 10.25 & 10.34 & 9.90 & 9.93 & 11.86 & 11.96 & 12.25 & 11.74 & 12.57 & 13.01 \\
\hline $\mathrm{MnO}$ & 31.79 & 32.34 & 31.72 & 31.65 & 31.65 & 30.32 & 29.92 & 29.32 & 29.45 & 28.82 & 28.33 \\
\hline $\mathrm{MgO}$ & 0.05 & 0.05 & 0.06 & 0.05 & 0.08 & 0.01 & 0.07 & 0.06 & 0.04 & 0.06 & 0.06 \\
\hline $\mathrm{CaO}$ & 0.24 & 0.33 & 0.42 & 0.40 & 0.39 & 0.25 & 0.36 & 0.24 & 0.25 & 0.21 & 0.23 \\
\hline $\mathrm{FeO}_{\text {calc }}$ & 10.28 & 9.68 & 9.77 & 9.35 & 9.38 & 11.20 & 11.30 & 11.57 & 11.09 & 11.87 & 12.29 \\
\hline $\mathrm{Fe}_{2} \mathrm{O}_{3 \text { calc }}$ & 0.60 & 0.57 & 0.57 & 0.55 & 0.55 & 0.66 & 0.66 & 0.68 & 0.65 & 0.70 & 0.72 \\
\hline Total & 99.00 & 99.30 & 99.23 & 97.87 & 98.38 & 100.12 & 99.94 & 99.65 & 99.42 & 99.45 & 99.18 \\
\hline${ }^{\mathrm{IV}} \mathrm{Si}$ & 5.837 & 5.886 & 5.915 & 5.908 & 5.913 & 6.008 & 6.007 & 6.037 & 6.053 & 6.031 & 6.051 \\
\hline${ }^{\mathrm{IV}} \mathrm{Al}$ & 0.163 & 0.114 & 0.085 & 0.092 & 0.087 & 0.000 & 0.000 & 0.000 & 0.000 & 0.000 & 0.000 \\
\hline${ }^{\mathrm{VI}} \mathrm{Al}$ & 3.930 & 3.948 & 4.013 & 4.003 & 4.031 & 4.076 & 4.086 & 4.113 & 4.135 & 4.137 & 4.109 \\
\hline $\mathrm{Fe}^{3+}$ & 0.076 & 0.071 & 0.072 & 0.070 & 0.069 & 0.081 & 0.082 & 0.084 & 0.081 & 0.087 & 0.090 \\
\hline $\mathrm{Ti}$ & 0.015 & 0.011 & 0.006 & 0.010 & 0.008 & 0.011 & 0.006 & 0.002 & 0.007 & 0.007 & 0.002 \\
\hline Sum A & 4.021 & 4.030 & 4.091 & 4.083 & 4.108 & 4.168 & 4.174 & 4.200 & 4.224 & 4.231 & 4.201 \\
\hline $\mathrm{Fe}^{2+}$ & 1.440 & 1.352 & 1.361 & 1.323 & 1.319 & 1.549 & 1.564 & 1.607 & 1.542 & 1.651 & 1.714 \\
\hline $\mathrm{Mn}$ & 4.484 & 4.547 & 4.457 & 4.510 & 4.483 & 4.229 & 4.175 & 4.099 & 4.128 & 4.035 & 3.979 \\
\hline $\mathrm{Mg}$ & 0.012 & 0.012 & 0.015 & 0.013 & 0.020 & 0.002 & 0.017 & 0.015 & 0.010 & 0.015 & 0.015 \\
\hline $\mathrm{Ca}$ & 0.043 & 0.059 & 0.075 & 0.072 & 0.070 & 0.044 & 0.063 & 0.042 & 0.044 & 0.037 & 0.041 \\
\hline Sum B & 5.979 & 5.970 & 5.909 & 5.917 & 5.892 & 5.824 & 5.819 & 5.763 & 5.724 & 5.738 & 5.748 \\
\hline$\Sigma$ Cat. & 16.000 & 16.000 & 16.000 & 16.000 & 16.000 & 16.000 & 16.000 & 16.000 & 16.000 & 16.000 & 16.000 \\
\hline Alm mol. \% & 19.5 & 18.2 & 23.1 & 19.1 & 22.4 & 26.6 & 26.9 & 27.9 & 27.0 & 28.8 & 29.8 \\
\hline Adr & 0.8 & 1.0 & 1.3 & 1.3 & 1.2 & 0.8 & 1.1 & 0.7 & 0.8 & 0.6 & 0.7 \\
\hline Sps & 79.5 & 80.6 & 75.3 & 79.4 & 76.1 & 72.6 & 71.7 & 71.1 & 72.0 & 70.3 & 69.2 \\
\hline Uv & 0.0 & 0.0 & 0.0 & 0.0 & 0.0 & 0.0 & 0.0 & 0.0 & 0.0 & 0.0 & 0.0 \\
\hline
\end{tabular}

\section{Discussion}

Despite the apparent simplicity of the IA pegmatite, different aspects regarding its origin and crystallization must be addressed: among them, its composite nature, structural attitude, bulk composition and stages of formation. The IA pegmatite is dominated by three essential minerals: quartz, albite and muscovite, which account for more than $95 \%$ of its volume. From the structural relationships

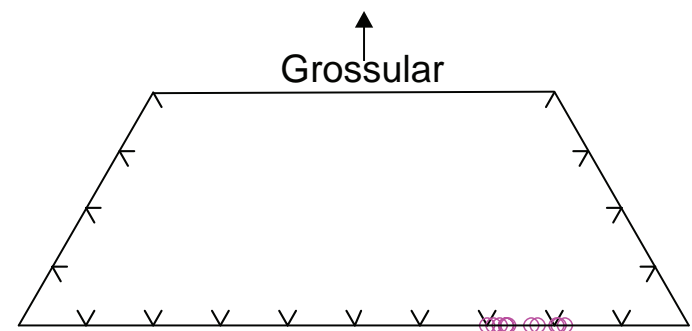

Almandine

Spessartine

Fig. 7 Composition of the garnet-supergroup minerals from the IA pegmatite (vol. \%). of its units, it is evident that IA is a composite pegmatite crystallized during at least two principal stages from two different batches of melt: the first formed the main pegmatite body (IA-1), discordantly intruded by the second one that formed the saccharoidal albite unit (IA-2). Both batches were consistent with magmatic physical conditions as the aureole of the pegmatite, mottled with poikiloblastic biotite and chlorite, document a contact metamorphic overprint on the host mica schist.

Because of its zonal asymmetry and local variation in the mineral associations, it is difficult to quantify the modal composition of the IA-1 pegmatite; however, a gross estimate is $\sim 35$ vol. $\% \mathrm{Qz}, 40 \% \mathrm{Ab}$ and $25 \% \mathrm{Ms}$. When this modal composition is transformed to chemical composition using the procedure of Friedman (1960) and then to CIPW normative content, the result is 35 wt. \% Qz, $40 \% \mathrm{Ab}, 18.3 \%$ Or and $6.7 \% \mathrm{Crn}$, which is not far from the composition of the $200 \mathrm{MPa}, \mathrm{H}_{2} \mathrm{O}$-saturated eutectic in the haplogranite system (34 wt. \% Qz, $38 \mathrm{wt} . \%$ $\mathrm{Ab}$, and 28 wt. \% Or, Fig. 8). The main mineralogical difference is that $\mathrm{K}$-feldspar is almost absent and muscovite is the major K-bearing phase. This implies that the 


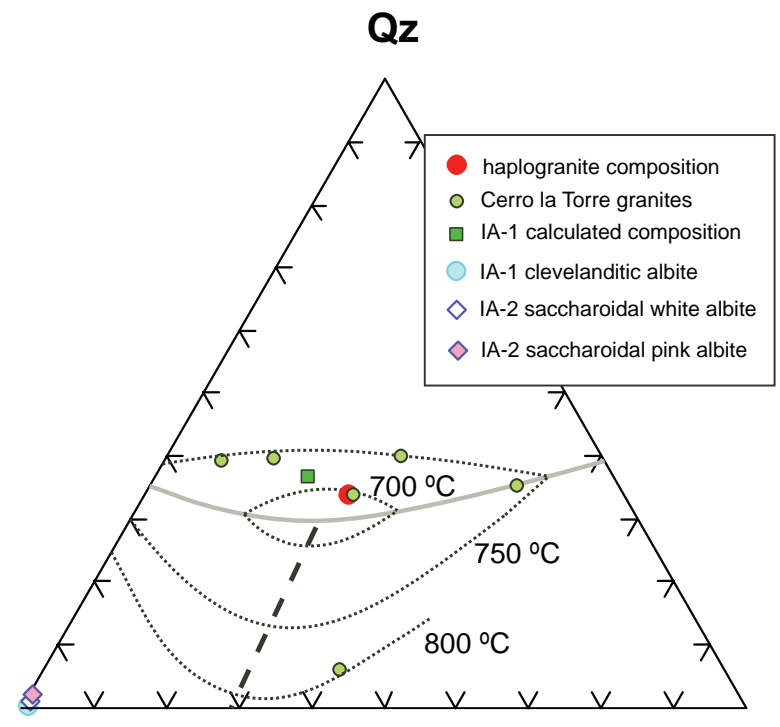

$A b$

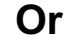

Fig. $8 \mathrm{Ab}-\mathrm{Qz}-\mathrm{Or}$ ternary projection of the CIPW normative values of the IA pegmatite compositions. Isotherms, showing $\mathrm{H}_{2} \mathrm{O}$-saturated haplogranite composition, and liquidus surface in the system $\mathrm{Ab}+\mathrm{Or}$ $+\mathrm{Qz}+\mathrm{H}_{2} \mathrm{O}$ at $200 \mathrm{MPa}$ are derived from Tuttle and Bowen (1958) and taken from London (2008).

$\mathrm{H}_{2} \mathrm{O}$ content of the melt, that probably was larger in IA-1 than in the beryl-type pegmatites of the Cerro La Torre group, would have shifted the system to within the stability field of muscovite (Burt 1981). Additionally, the IA-1 pegmatite melt was subject to tectonic necking-down after emplacement, and the main body widened and was sealed from the northern and southern parts. These conditions yielded asymmetry in the sequential crystallization that promoted increasing contents of muscovite + quartz and then of quartz from the west to the east sides of the pegmatite. The low $\mathrm{Li}$, the relatively high content of $\mathrm{H}_{2} \mathrm{O}$ (indicated by the high proportion of muscovite), the high $\mathrm{Mn}$ in the fluorapatite, and the presence of Ta-bearing minerals suggest that the melt composition was rather evolved. It possibly represented a product of fractionation from either a parental leucogranite or a slightly Li-richer hidden rare-element pegmatite at an advanced stage of crystallization.

The saccharoidal albite unit (IA-2) was formed by crystallization from a melt that discordantly intruded IA-1, crosscutting different zones already crystallized and, in part, also the host rock. The mineralogy of this unit is simple and quite uniform: albite plus trace contents of columbite-group minerals and fluorapatite. Its bulk chemical composition is close to that of pure albite with ASI $\sim 1$, and normative composition shows a melt just saturated in silica, almost completely albitic (Tab. 1, Fig. 8). The physical conditions in the system $\mathrm{NaAlSi}_{3} \mathrm{O}_{8}-\mathrm{H}_{2} \mathrm{O}$ with different fluxes $(\mathrm{F}, \mathrm{Cl}, \mathrm{B}, \mathrm{P})$ at variable pressures and incidence of this system in the residual pegmatitic system have been addressed experimentally by several authors (e.g., Swanson and Fenn 1992; Shen and Keppler 1997; Sowerby and Keppler 2002). From these works, it is known that the liquidus in the albite- $\mathrm{H}_{2} \mathrm{O}$ system is lowered considerably by the presence of $\mathrm{F}, \mathrm{B}$ and $\mathrm{P}$ at $\sim 800-600^{\circ} \mathrm{C}$. However, empirical observations of the timing of formation of some albite-rich units in granitic pegmatites (the fracture-controlled replacement bodies of Cameron et al. 1949) and experiments with pegmatitic melts (London et al. 1989) both show that temperatures must be considerably lower, estimated in the range $\sim 600-450^{\circ} \mathrm{C}$, at $2-3 \mathrm{MPa}$. These conditions give an appropriate framework for the crystallization of IA-2. With these inferred compositional parameters, it is surprising that albite crystallized with a saccharoidal texture instead of a coarser-grained tabular habit, as it should be according to the results of Swanson and Fenn (1992). The saccharoidal texture is attributed to a sudden increase in the nucleation rate of albite, triggered by a dramatic loss of the $\mathrm{H}_{2} \mathrm{O}-$-rich, P-, F- and possibly B-enriched vapor phase (Jahns and Burnham 1969). In the present case, this could be due to the tectonic forces opening the closed magma chamber in which the IA-2 melt was crystallizing after its forceful intrusion. The uniform chemistry and small grain size of the columbite-group minerals in IA-2 (Figs 5, 6b) reinforce this interpretation. Local evidence for at least P and F loss is shown in Fig. 4d, where fluorapatite crystals were introduced metasomatically into the muscovite-rich pegmatite unit (IA-1) hosting the IA-2 albite vein.

London et al. (1989) demonstrated that, at terminal stages of fractionation of an initially $\mathrm{H}_{2} \mathrm{O}$-unsaturated rare-element-bearing pegmatitic melt (the Macusani peraluminous rhyolitic obsidian), $\mathrm{Na} / \mathrm{K}$ increases progressively in the remnant melt due to the presence of F, P, B and $\mathrm{H}_{2} \mathrm{O}$. This yields almost pure albite before crystallizing abundant quartz, Li-mica and pollucite. The albite fraction also concentrates HFSE, especially $\mathrm{Nb}$ and Ta. Veksler et al. (2002), in turn, showed experimentally that in pegmatitic melts enriched by $\mathrm{H}_{2} \mathrm{O}, \mathrm{B}, \mathrm{P}$ and $\mathrm{F}$, three immiscible fluids can coexist. These have properties of an aluminosilicate melt, a hydrosaline melt and a hydrous fluid, respectively. The hydrosaline melt is strongly enriched in F, B, and $\mathrm{P}$ and fractionates $\mathrm{Na}$ from $\mathrm{K}$, the latter being concentrated in the aluminosilicate melt. While the chemical composition of this hydrosaline melt differs from that of IA-2, the starting experimental pegmatite melt did not have a haplogranite composition, either. Consequently, a melt with the chemistry of IA-2 could have originated from a crystal-melt fractionation or from an immiscibility episode during ongoing crystallization. The homogeneous chemical composition of IA-2, as well as a comparison of its volume with that of the whole pegmatite, and the absence of a complementary unit that 
would represent the other immiscible part of the system, suggest that the most likely mechanism was fractional crystallization. As at the previous IA-1 stage, the melt could have originated either from a parental pegmatitic leucogranite or from a rare-element granitic pegmatite, in both cases at its final stages of fractionation (London 2008). Nevertheless, the occurrence circumscribed to the limits of the IA-1 pegmatite and its moderate volume strongly suggest that the second possibility is more probable. If this is the case, the usually inwardly concentric path of crystallization of subvertically emplaced rare-element pegmatites was transformed into an upward sequential intrusion of melts that were tectonically extracted in the successive two latest stages of evolution of a larger parental pegmatite.

In this way, IA represents one of the most evolved natural results of complete fractionation of Li-poor granitic melts, starting from an S-type pegmatitic leucogranite (Cerro La Torre), passing probably through a fractionated rare-element pegmatite melt stage, and finishing with IA-1. This latest product shifted to a HFSE-flux-bearing albite melt of near-alkaline and silica-saturated composition as shown here, similar to that described by London (2008, p. 288).

The strained textures of the mineral assemblages of IA-1, the widened bulbous shape of its main portion, and the asymmetric distribution of its internal zones demonstrate that it underwent deformation during, and after, its crystallization. In addition to this syn-kinematic deformation, a post-kinematic tectonic tilting of the entire basement block that contains the IA pegmatite may have occurred, although evidence for this is limited. IA-2 lies preferentially in the hanging wall of IA-1, whereas in most of albite-type pegmatites elsewhere the saccharoidal albite zone occurs in the footwall (Černý 1989). In addition, the metasomatic fluorapatite introduced into the host rock by the saccharoidal albite vein (Fig. 4d) appears in the footwall, yet its normal position should be in the hanging wall considering that it was formed by escape of volatiles (P, F). Similarly, the subsidiary branching of saccharoidal albite (Fig. 4c) would be more rational in the hanging wall of IA-1.

\section{Conclusions}

The Independencia Argentina granitic pegmatite belongs to the albite-type of the REL-Li class, compositionally and mineralogically among the most distal representatives of the rare-element pegmatites of the Cerro La Torre group. It is a composite, zoned pegmatite formed in a two-stage process that involved a $\mathrm{H}_{2} \mathrm{O}$-enriched pegmatitic melt, syn-kinematically intruded and crystallized, followed by the discordant emplacement of a highly evolved, Na-HFSE-rich, fluxed, residual melt. Rapid crystallization produced a saccharoidal albite unit. Both batches of melts were possibly derived by fractionation of a hidden rare-element pegmatite that underwent sequential extraction of remnant melts at different stages of the crystallization.

Acknowledgements. The authors are very thankful to T. Soldberg, F. Colombo and A. Guereschi for the help while microprobing the minerals and to Karen Ferreira for her assistance with the manuscript. The authors are very grateful also to David London for the comments on an earlier version of this paper that helped to interpret the experimental data. Grants PIP 857 of CONICET and PICT 21638 of FONCYT financed partially the research. The authors thank S. Swanson and A. Lima for thorough reviews and comments that have greatly helped to improve the manuscript. The editorial handling and comments of Milan Novák and the help in improving this manuscript by the editor Vojtěch Janoušek are much appreciated.

\section{References}

BURT DM (1981) Acidity-salinity diagrams; applications to greisen and porphyry deposits. Econ Geol 76: 832-843

Cameron EN, Jahns RH, McNair AH, Page LR (1949) Internal structure of granitic pegmatites: Econ Geol, Monograph 2: pp 1-115

ČERNÝ P (1989) Characteristics of pegmatite deposits of tantalum. In: Möller P, Černý P, SAupé F (eds) Lanthanides, Tantalum and Niobium. Society for Geology Applied to Mineral Deposits, Special Publications 7. Springer-Verlag, Berlin, pp 195-239

ČERNÝ P (1992) Regional zoning of pegmatite populations and its interpretation. Mitt Österr Min Ges 137: 99-107

ČERNÝ P (2005) The Tanco rare-element pegmatite deposit, Manitoba: regional context, internal anatomy, and global comparisons. In: LinNen RL, SAmson IM (eds) RareElement Geochemistry and Mineral Deposits. Geological Association of Canada, Short Courses Notes 17: 127-158

ČERNÝ P, ERCIT TS (2005) The classification of granitic pegmatites revisited. Canad Mineral 43: 2005-2026

ČERNÝ P, ERCIT TS, WisE MA (1992) The tantalite-tapiolite gap: natural assemblages versus experimental data. Canad Mineral 30: 587-596

FriedMAN GM (1960) Chemical analyses of rocks with the petrographic microscope. Amer Miner 45: 69-78

GALLISKI MA (2013) Regional zoning in a LCT (Li, Cs, Ta) granite-pegmatite system in the Eastern Pampean Ranges of San Luis, Argentina. In: Simmons WB, Webber KL, Falster aU, Roda-Robles E, Hanson SL, MarquezZavalía MF, Galliski MA (eds) Contributions to the 
$6^{\text {th }}$ International Symposium on Granitic Pegmatites, Abstracts. Rubellite Press, New Orleans pp 47-48

Galliski MA, Márquez-Zavalía MF, Oyarzábal JC, CorTONA O (1994) Geology of a pegmatite of albite type: Independencia Argentina mine. Rev Asoc Geol Argentina 49: 306-312 (in Spanish)

Galliski MA, Perino E, Gázquez J, Márquez-Zavalía MF, Olsina R (1997) K-feldspar and white mica trace-element contents as a geochemical guide for pegmatite exploration in the Pampean Pegmatite Province. Rev Asoc Geol Argentina 52: 24-32 (in Spanish)

JAHNS RH, Burnham CW (1969) Experimental studies of pegmatite genesis. I. A model for the derivation and crystallization of granitic pegmatites. Econ Geol 64: 843-864

London D (2008) Pegmatites. The Canadian Mineralogist, Special Publications 10: 1-347

London D, Morgan GB, Hervig RL (1989) Vapor-undersaturated experiments in the system macusanite $+\mathrm{H}_{2} \mathrm{O}$ at $200 \mathrm{MPa}$, and the internal differentiation of granitic pegmatites. Contrib Mineral Petrol 102: 1-17

Oyarzábal JC, Galliski MA, Perino E (2009) Geochemistry of K-feldspar and muscovite in rare-element pegmatites and granites from the Totoral pegmatite field, San Luis, Argentina. Resour Geol 59: 315-329

Pollard PJ (1989) Geologic characteristics and genetic problems associated with the development of granite-hosted deposits of tantalum and niobium. In: Möller P, ČERNÝ P, SAupé F (eds) Lanthanides, Tantalum and Niobium. Society for Geology Applied to Mineral Deposits, Special Publications 7, Springer-Verlag, Berlin, pp 240-256

Pouchou JL, Pichoir F (1985) "PAP" ( $\varphi \rho Z)$ correction procedure for improved quantitative microanalysis. In: Armstrong JT (ed) Microbeam Analysis. San Francisco Press, San Francisco, pp 104-106

Shen AH, Keppler H (1997) Direct observation of complete miscibility in the albite $-\mathrm{H}_{2} \mathrm{O}$ system. Nature 385 : 710-712
Sims JP, Ireland TR, Camacho A, Lyons P, Pieters RG, Stuart-Smith PG, Miró R (1998) U-Pb, Th-Pb and $\mathrm{Ar}-\mathrm{Ar}$ geochronology from the Southern Sierras Pampeanas, Argentina: implications for the Paleozoic tectonic evolution of the western Gondwana margin. In: Pankhurst RJ, Rapela CA (eds) The Proto-Andean Margin of Gondwana. Geological Society of London Special Publications 142: 259-281

Sowerby J R, KepPler H (2002) The effect of fluorine, boron and excess sodium on the critical curve in the albite- $\mathrm{H}_{2} \mathrm{O}$ system. Contrib Mineral Petrol 143: 32-37

Steenken A, López de Luchi MG, Martínez Dopico C, Drobe M, Wemmer K, Siegesmund S (2011) The Neoproterozoic-early Paleozoic metamorphic and magmatic evolution of the Eastern Sierras Pampeanas: an overview. Int J Earth Sci 100: 465-488

Swanson SE, Fenn PM (1992) The effect of $\mathrm{F}$ and $\mathrm{Cl}$ on the kinetics of albite crystallization: a model for granitic pegmatites? In: Martin RF, Černý P (eds) Granitic Pegmatites. Canad Mineral 30: 549-559

Sweetapple MT, Collins PLF (2002) Genetic framework for the classification and distribution of Archean rare metal pegmatites in the North Pilbara Craton, Western Australia. Econ Geol 97: 873-895

Tuttle OF, Bowen NL (1958) Origin of granite in the light of experimental studies in the system $\mathrm{NaAlSi}_{3} \mathrm{O}_{8}-$ $\mathrm{KAlSi}_{3} \mathrm{O}_{8}-\mathrm{SiO}_{2}-\mathrm{H}_{2} \mathrm{O}$, Geological Society of America, Memoirs 74: 1-151

Veksler IV, Thomas R, Schmidt C (2002) Experimental evidence of three coexisting immiscible fluids in synthetic granitic pegmatite. Amer Miner 87: 775-779

von Quadt A, Galliski MA (2011) U-Pb LA-ICPMS columbite-tantalite ages from the Pampean pegmatite province: preliminary results. Asociación Geológica Argentina, Serie D, Special Publications 14: 221-223

Whitney DL, Evans BW (2010) Abbreviations for names of rock-forming minerals. Amer Miner 95: 185-187 